\title{
Red blood cell and white blood cell counts in sandpipers (Philomachus pugnax, Calidris canutus): effects of captivity, season, nutritional status, and frequent bleedings
}

\author{
Theunis Piersma, Anita Koolhaas, Anne Dekinga, and Eberhard Gwinner
}

\begin{abstract}
Captive ruffs (Philomachus pugnax) and red knots (Calidris canutus) kept in small flocks in outdoor aviaries maintained body mass and plumage cycles resembling those of free-living conspecifics. The persistence of identifiable annual cycles enabled us to study variability in two blood parameters, one a measure of red blood cell count (hematocrit) and the other an index of white blood cell (WBC) abundance (percentage). In both species hematocrit values averaged 0.43 , somewhat lower than those measured in free-living red knots. Hematocrit varied little with time of year and we were unable to convincingly confirm predicted elevated hematocrit levels during periods of storage of fat for migration. In both species the percentage of WBCs (percent WBCs) initially declined from 0.6 to $0.8 \%$; levels stabilized at $0.4 \%$ in ruffs and $0.3 \%$ in red knots after half a year in captivity. Using observations of the same individual red knots in the years before and after the experimental year as controls, biweekly extraction of about $30 \%$ of blood volume did not negatively affect seasonal changes in body mass and moult and breeding-plumage cycles. In nutritionally stressed red knots, hematocrit levels were low, and in these birds only, the small wounds inflicted by bleeding healed with difficulty.
\end{abstract}

Résumé : Chez des Combattants variés (Philomachus pugnax) et des Bécasseaux maubèches (Calidris canutus) gardés en captivité en petites bandes dans des volières extérieures, les cycles de la masse corporelle et du plumage étaient semblables à ceux d'oiseaux libres. Le maintien d'un cycle annuel défini nous a permis d'étudier la variabilité de deux paramètres sanguins, l'un indicateur de la concentration d'érythrocytes (l'hématocrite) et l'autre indicateur de l'abondance des leucocytes (le pourcentage). Chez les deux espèces, la valeur de l'hématocrite était de 0,43 en moyenne, une valeur relativement plus basse que celle des Bécasseaux maubèches en liberté. L'hématocrite a subi peu de variations au cours de l'année et nous avons été incapables de confirmer la prédiction selon laquelle la valeur de l'hématocrite augmenterait pour des périodes de mise en réserve des graisses à l'approche de la migration. Chez les deux espèces, le pourcentage de leucocytes, de $0,6-0,8 \%$ à l'origine, a baissé pour se stabiliser à $0,4 \%$ chez les combattants et à $0,3 \%$ chez les bécasseaux après une demi-année en captivité. En utilisant les résultats de nos observations des mêmes bécasseaux au cours de l'année précédente et de l'année suivante comme témoins, nous concluons que l'extraction bihebdomadaire de $30 \%$ du volume sanguin n'a pas affecté négativement les changements saisonniers de la masse corporelle, la mue ou le plumage. Chez les bécasseaux soumis à un stress alimentaire, l'hématocrite était bas et seulement ces oiseaux ont eu de la difficulté à se remettre des petites blessures infligées lors des saignées.

[Traduit par la Rédaction]

\section{Introduction}

In ecological studies of vertebrates, blood parameters are increasingly used (Payne and Payne 1987) to assess health

Received December 7, 1999. Accepted April 18, 2000.

T. Piersma, ${ }^{1}$ A. Koolhaas, and A. Dekinga. Netherlands Institute for Sea Research (NIOZ), P.O. Box 59, 1790 AB Den Burg, Texel, the Netherlands, and Centre for Ecological and Evolutionary Studies, University of Groningen,

P.O. Box 14, 9750 AA Haren, the Netherlands.

E. Gwinner. Research Centre for Ornithology of the MaxPlanck-Gesellschaft, von der Tannstraße 7, D-82346 Andechs, Germany.

${ }^{1}$ Author to whom all correspondence should be addressed (e-mail: theunis@nioz.nl). and vigour in particular behavioural or experimental contexts (e.g., Saino et al. 1997; Horãk et al. 1998; Ots et al. 1998). The most commonly used measure of red blood cell count is the hematocrit (the percentage of packed red blood cells per unit blood volume). The relative amount of white blood cells (WBCs) can also be measured quite easily as the relative depth of the buffy coloured layer in capillary tubes after centrifuging. Descriptions of the extent of seasonal changes in blood parameters in both free-living and captive birds (de Graw et al. 1979; Gessaman et al. 1986; Ferrer et al. 1987; Hüppop 1988), of which the latter can be sampled repeatedly, provide a yardstick for comparison (Prinzinger and Misovic 1994). For example, in two species of sandpipers (ruff, Philomachus pugnax, Banerjee and Banerjee 1977; bar-tailed godwit, Limosa lapponica, Piersma et al. 1996), hematocrit levels were reported to be elevated before 
long-distance flights. More generally, long-distance migrants may have higher hematocrit levels than most other birds (Wingfield et al. 1990).

Small blood samples taken after capture of free-living and captive birds are increasingly used to study hormonal processes, prevalence of blood parasites, sexual identity, and paternity (Wingfield and Farner 1976; Loye and Zuk 1991; Griffiths et al. 1996; Ellegren and Sheldon 1997; Wingfield et al. 1997; Baker et al. 1999). This raises the question of whether these invasive procedures inflict undue stress on the birds with respect to both behaviour and physiology (Dawkins and Gosling 1992). Studies on wild-caught birds in natural settings are required to study behavioural responses (Lubjuhn et al. 1998). However, longitudinal studies on captive individuals yield better controlled observations of the long-term effects of (repeated) bleeding on physiological parameters.

In the present study we describe seasonal changes in red blood cell and WBC counts in two sandpiper species, ruff and red knot (Calidris canutus), that even in captivity show quite natural mass and plumage cycles (Piersma et al. 1995; Melter and Bergmann 1996; Piersma and Ramenofsky 1998). In the case of the red knots, observations on mass and plumage cycles in the years before and after a year of frequent bleeding provide a control for those parameters. Additional observations on red knots under nutritional stress are used to confirm our prediction that in well-fed animals, intense blood sampling will not negatively affect hematological profiles.

\section{Material and methods}

\section{Aviaries}

Ruffs and red knots were kept in small flocks of three to eight birds in outdoor aviaries measuring $2 \times 4 \mathrm{~m}$, with a height of $2 \mathrm{~m}$ (Piersma and Ramenofsky 1998). The rubber-coated concrete floor that covered three-quarters of the surface was kept wet with seawater sprinklers along one edge of the aviary. One-quarter of the surface of the cage was occupied by a shallow basin with sand and running seawater. Each aviary contained a small freshwater basin for drinking and bathing. The birds were fed ad libitum portions of protein-rich trout-food pellets, except for six red knots that were examined after having been maintained on a natural diet of shellfish for more than a month.

Once per week the birds were taken out of the aviaries for a few hours and screened for physical condition, moult, and body mass. Any infections of feet and bill or elsewhere on the body were carefully registered. Body mass was measured on an electronic balance to the nearest $1 \mathrm{~g}$, and the extent of breeding plumage was scored on a scale of 1-7 (1 indicating full gray winter plumage, 2 a trace of breeding plumage, 3 one-quarter breeding plumage, etc., up to 7 indicating full rusty-red breeding plumage). During the absence of the birds the aviaries were cleaned and disinfected and the food trays refilled.

\section{Blood sampling and hematological procedures}

Always within $15 \mathrm{~min}$, and usually within $5 \mathrm{~min}$, after their entry into the aviary, the brachial wing vein of the birds was lightly punctured and blood collected in heparinized microhematocrit capillary tubes $(50 \mu \mathrm{L})$. After 3-5 capillary tubes had been obtained, bleeding had usually stopped, or was stopped by pressing a piece of cotton wool on the small wound. We used fresh sterile needles for every new puncture. The capillary tubes were stored $\operatorname{cool}\left(3^{\circ} \mathrm{C}\right)$ and centrifuged within $2 \mathrm{~h}$ at $6900 \times g$ for $15 \mathrm{~min}$. The layer of compacted red blood cells was measured with a ruler to the nearest $1 \mathrm{~mm}$, and so was the total blood volume. Hematocrit was calcu- lated as the percent cellular fraction of the total blood volume of all microcapillary tubes per sampling session combined. To measure the contribution of WBCs, the height of the thin white or greyish "buffy layer" between the plasma and the compacted red blood cells was measured to the nearest $0.01 \mathrm{~mm}$ at $50 \times$ magnification under a binocular microscope mounted with an ocular micrometer. The percentage of WBCs in the total blood volume was calculated in a similar way to the hematocrit.

\section{Birds and experimental protocols}

The six male ruffs in this study were all captured in the province of Friesland on 15 March 1997 using a "wilsternet" (Koopman and Hulscher 1979). The six red knots were all captured with mist nets near a high-tide roost on Wieringen in the western Dutch Wadden Sea. Three birds (all adult males) were caught on 6 November 1994, and another three adults (two females and a male) on 27 October 1995. Based on capture date and seasonal body mass characteristics, all red knots can be assigned to the Europe-wintering subspecies islandica (Davidson and Wilson 1992; Piersma and Davidson 1992). Sex was determined by means of a standard molecular assay (Baker et al. 1999).

In the context of a study on daily and annual rhythms in plasma melatonin concentration (E. Gwinner, T. Piersma, A. Koolhaas, T. van't Hoff, unpublished data) from early March 1997 to late February 1998, except for a period in midsummer 1997, these birds went through biweekly 24-h sessions, starting and ending at midday with seven bleedings at 4-h intervals. During such sessions they thus lost about 5 (tubes) $\times 0.05(\mathrm{~mL}) \times 7=1.75 \mathrm{~mL}$ of blood, which is about $1.5 \%$ of the body mass of red knots and may thus represent about $1.75 /(0.05 \times 120)=29 \%$ of the blood volume of these birds (assuming that the total mass of blood is about $5 \%$ of body mass; Sturkie 1986, p. 104). In the slightly heavier ruffs the relative amount of blood taken will have been lower.

The relevance of the observations on body mass and plumage cycles would be of limited value without a suitable control. In the case of the red knots, the observations made on the same individuals during the year before and the year after the 12-month period of biweekly bleeding provide such a control.

The interaction between nutritional status and tolerance of blood sampling was studied inadvertently in an experiment involving another six red knots of the islandica subspecies (three males and three females) that were captured on 9 February 1997 near the island of Griend in the western Dutch Wadden Sea. They were initially kept in outdoor aviaries on a diet of trout-food pellets. From the last week of November 1997 onwards, however, they were housed in an indoor aviary at air temperatures of $15-20^{\circ} \mathrm{C}$. Here we trained the birds to eat edible cockles (Cerastoderma edule) on an artificial mud flat. As red knots with pellet-induced atrophy of the gizzard are initially reluctant to eat these hard-shelled prey (Piersma et al. 1993), birds were first given easy-to-crack small bivalves, then proceeded to larger ones. During this process the birds initially lost body mass. As body mass stabilized, we attempted to increase the amount of cockles they would eat per unit of time, so that they could be in balance by feeding for $8 \mathrm{~h}$ per day, a situation that often occurs under field conditions (T. Piersma, unpublished observations). During this training procedure their masses continued to decline, although not to levels that would put them in any danger of death from starvation. (It turned out that the cockles used contained rather little meat per unit calcimass ingested, which explains why the red knots were not able to remain in energy balance when their feeding period was limited to $8 \mathrm{~h}$ (A. Dekinga, T. Piersma, G.H. Visser, and B. Achterkamp, unpublished data).) Nevertheless, during an experiment carried out on 6 January 1998 to measure daily energy expenditure and water turnover, which necessitated blood-sampling twice, it seemed that the blood was rather "thin" (indicating low hematocrit values), and bleeding did not stop easily. In addition, the small wounds had not healed within a 
Fig. 1. Changes in body mass (A), extent of breeding plumage (B), hematocrit (fraction) (C), and percentage of white blood cells (percent WBCs) (D) for six male ruffs kept from early March 1997 to late February 1998 in two outdoor aviaries. Box plots with average values (dots) are presented. In C and D the horizontal lines indicate the overall averages.
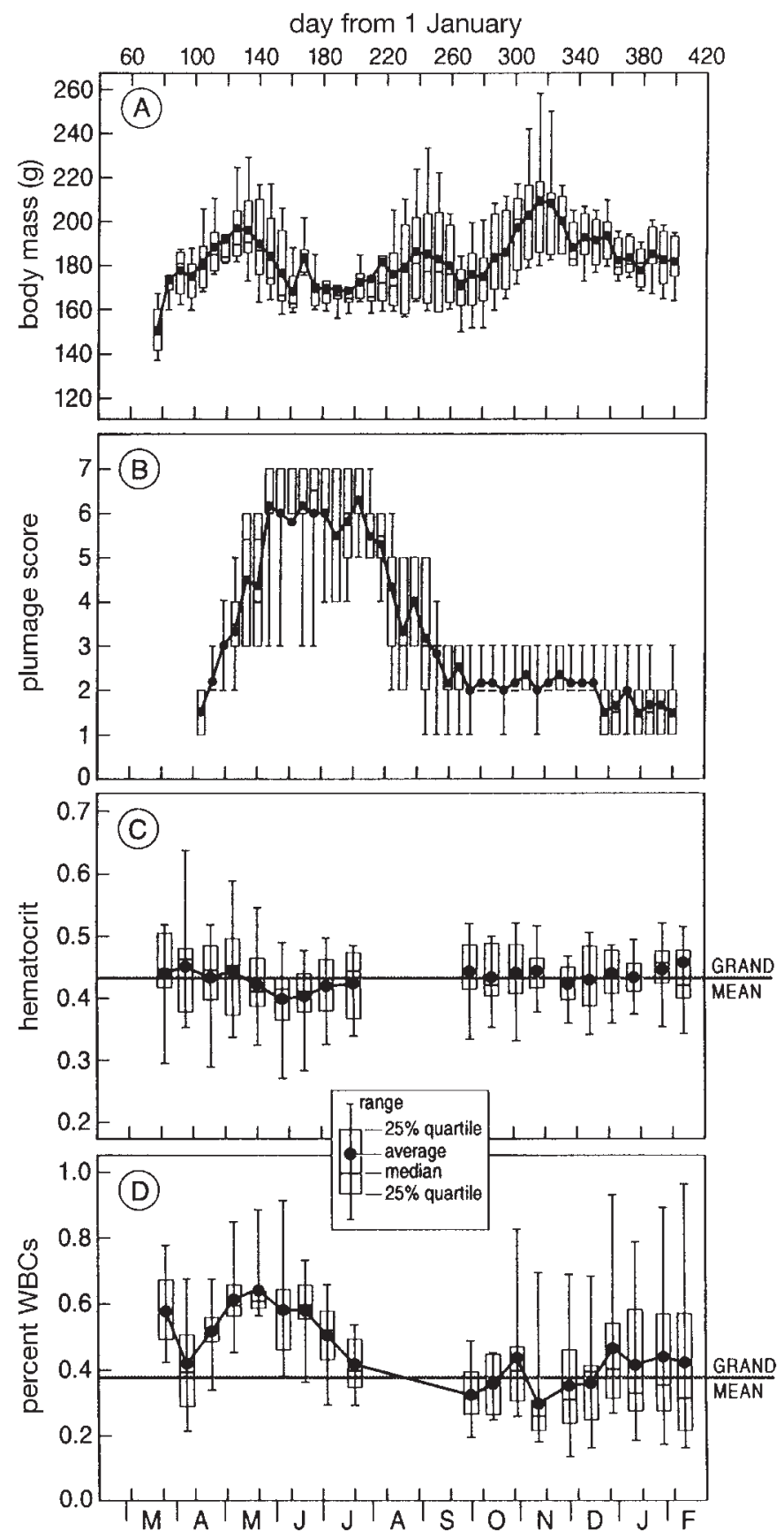

period of $12 \mathrm{~h}$, as wounds due to bleeding always do under normal circumstances. Therefore, we examined the healing in detail (scoring the extent to which the wound healed in the course of the day on a scale from $1=$ no healing to $10=$ a dry and completely healed wound), and measured the hematological parameters on 7 January. We repeated the hematological assays after a week and then after another week. During this time the birds were allowed to eat portions of trout pellets in addition to cockles.

\section{Results}

\section{Ruffs under ad libitum food conditions}

Body masses of the six male ruffs varied between 170 and about $240 \mathrm{~g}$ (Fig. 1A), similar to their values in the field (Koopman 1986; Jukema et al. 1995). They initially increased in mass, probably reflecting fuel storage for onward migration, and then had a period of low body mass, perhaps initially reflecting the breeding period, in view of the development of their colourful breeding plumage (Fig. 1B). From July onwards they showed two more periods when body mass increased, in fact reaching masses higher than in spring. These peaks might reflect episodes of fuel storage necessary for flight from the boreal and subarctic breeding grounds to the temperate staging grounds, where a partial wing moult takes place (as it did in this study), before an onward long-distance flight to West Africa (Koopman 1986). Throughout these lows and highs in body mass, hematocrit stayed remarkably constant at an average of about 0.43 (Fig. 1C), despite a field report that ruffs increase their red blood cell count before northward migration (Banerjee and Banerjee 1977). The percentage of WBCs to total blood volume (Fig. 1D) was initially maintained at $0.6 \%$, with a temporary drop, then declined over the summer and remained fairly stable at about $0.4 \%$ for the rest of the year. After $24 \mathrm{~h}$ and six blood samplings, ruffs had, not surprisingly, lost enough blood to depress the hematocrit (Fig. 2A), but there was no clear change in the percentage of WBCs (Fig. 3A). The changes over the subsequent 2 weeks mirrored those during the 24-h sampling episode: the hematocrit recovered (Fig. 2C) and there was no change in the percentage of WBCs (percent WBCs) (Fig. 3C).

\section{Red knots under ad libitum food conditions}

The six red knots showed body-mass cycles typical of captive individuals of the islandica subspecies (Piersma et al. 1995; Piersma and Ramenofsky 1998), with a sharp peak in mass in late May and early June, the absence of a mass peak in autumn indicating southward migration, and a much smaller elevation in mass in midwinter (Fig. 4A). Compared with the year before and the year after the experiment, the variations in mass were similar, even though the winter mass values typically (see Piersma et al. 1995) became somewhat smaller over the years in captivity (Fig. 4A). The mass changes were perfectly normal during the year that the birds were intensely bled at 2-week intervals, and the extent and timing of development of the breeding plumage were completely normal (Fig. 4B). If anything, the red knots improved in the extent of their breeding plumage over the course of their time in captivity.

Hematocrit varied between 0.3 and 0.5 , with an average of 0.43 (Fig. 4C). There were some changes in the early part of the study, possibly correlated with the storage and depletion of fuel for migration (Fig. 4A), but otherwise the only trend was a slight increase, rather than a decrease, over the course of the year of study (Fig. 4C). As in the ruffs, hematocrit levels dropped during the course of the $24 \mathrm{~h}$ of bleeding sessions (Fig. 2B), and no clear change could be detected in percent WBCs (Fig. 3B). Also, the changes over the subsequent 2 weeks mirrored those during the 24-h sampling episode: hematocrit recovered (Fig. 2D) and there was no change 
Fig. 2. Changes in hematocrit after seven successive bleedings of male ruffs and red knots within 24 h (A and B, respectively) and over the next 2 weeks ( $\mathrm{C}$ and $\mathrm{D}$, respectively). Data points for all dates and all individual birds per species have been assembled in these scattergrams.

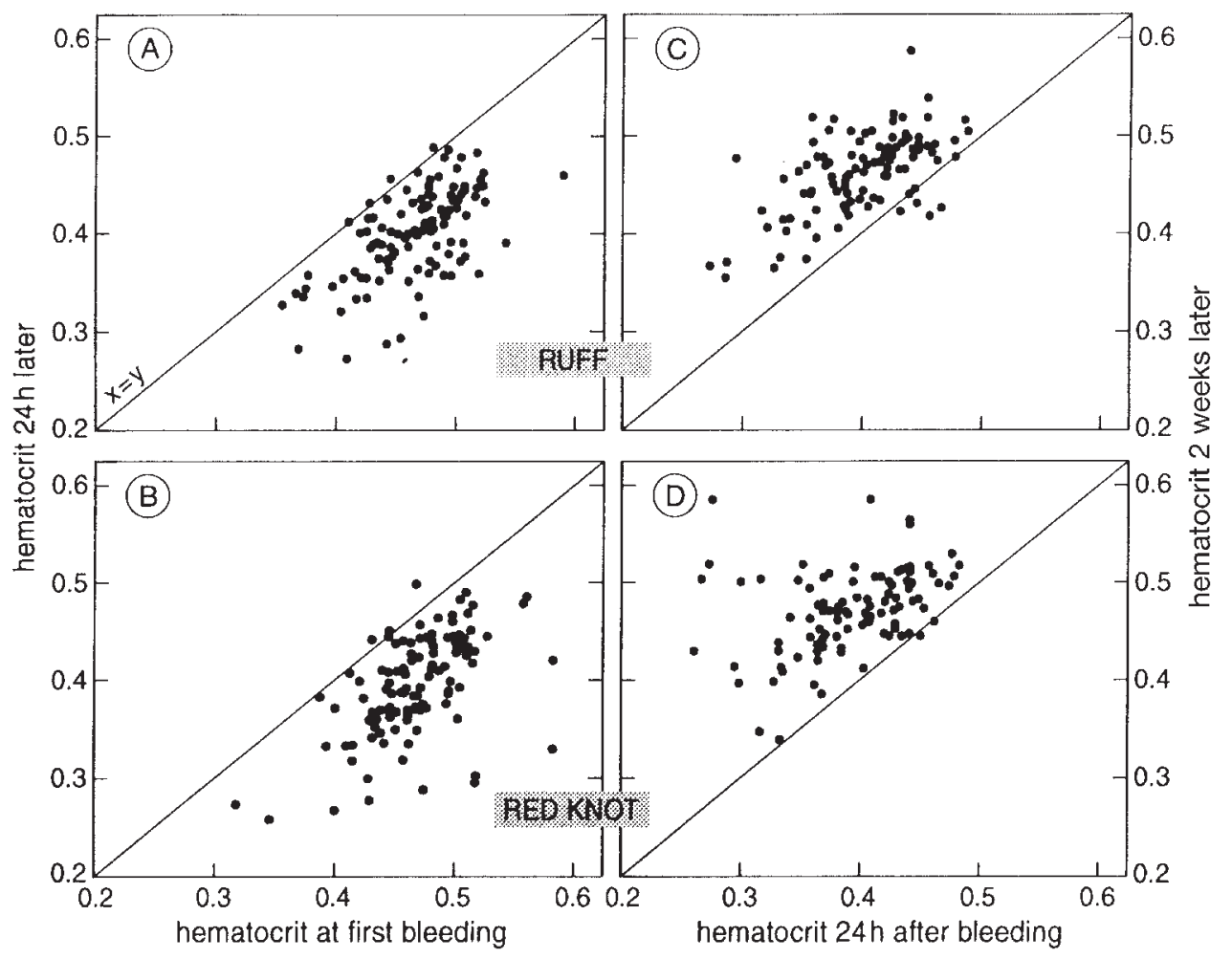

Fig. 3. Changes in percent WBCs after seven successive bleedings of male ruffs and red knots within 24 h (A and B, respectively) and over the next 2 weeks ( $\mathrm{C}$ and $\mathrm{D}$, respectively). Data points for all dates and all individual birds per species have been assembled in these scattergrams.

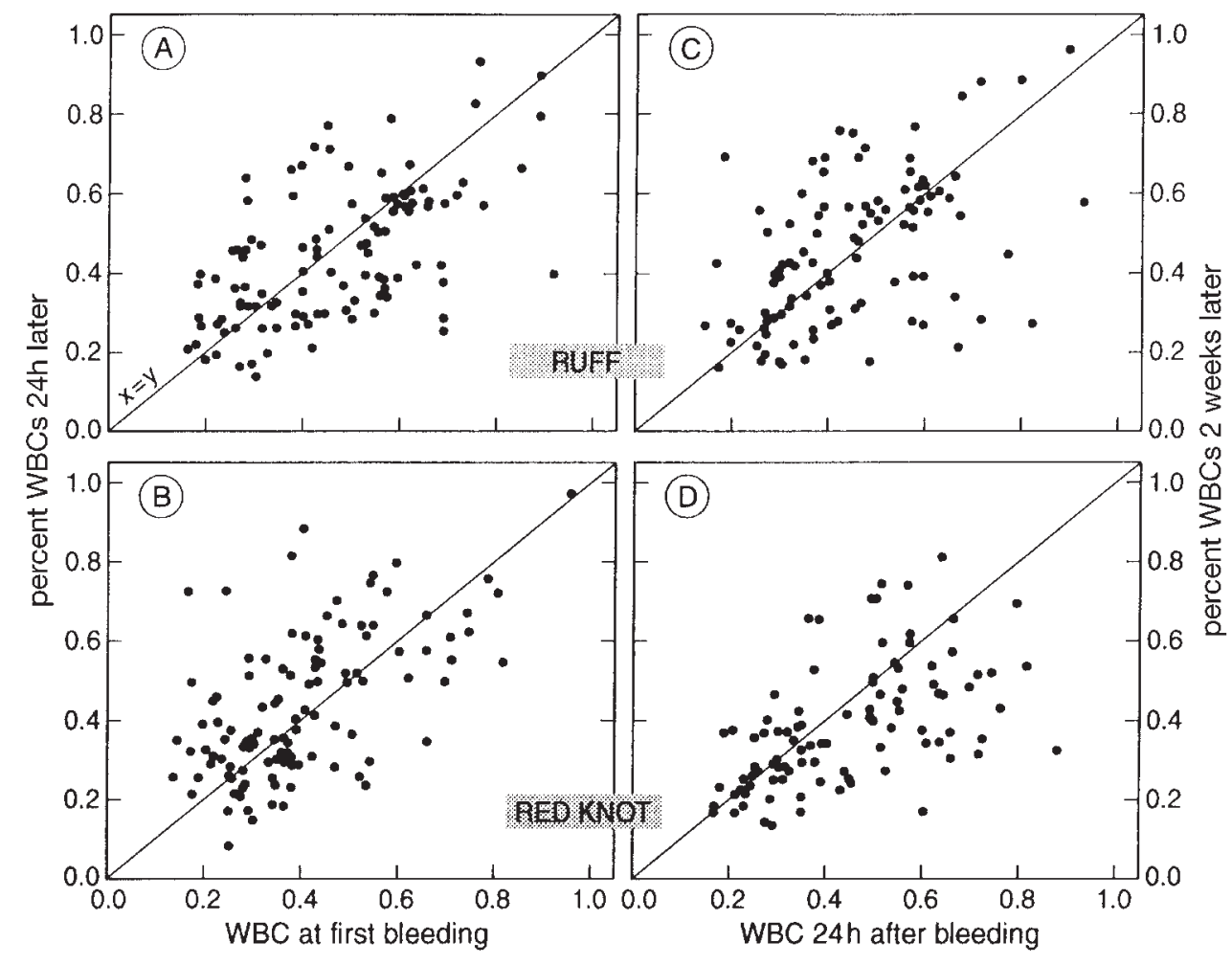


Fig. 4. Changes in body mass (A), extent of breeding plumage (B), hematocrit (C), and percent WBCs (D) for six red knots kept for 3 years in outdoor aviaries. The mass and plumage values for the year (February 1997 - February 1998) that birds were bled at 2-week intervals are given as box plots as in Fig. 1, but the average values of these parameters for the year before and the year after are also shown as open circles and solid circles, respectively. In $\mathrm{C}$ and $\mathrm{D}$ the horizontal lines indicate the overall averages.

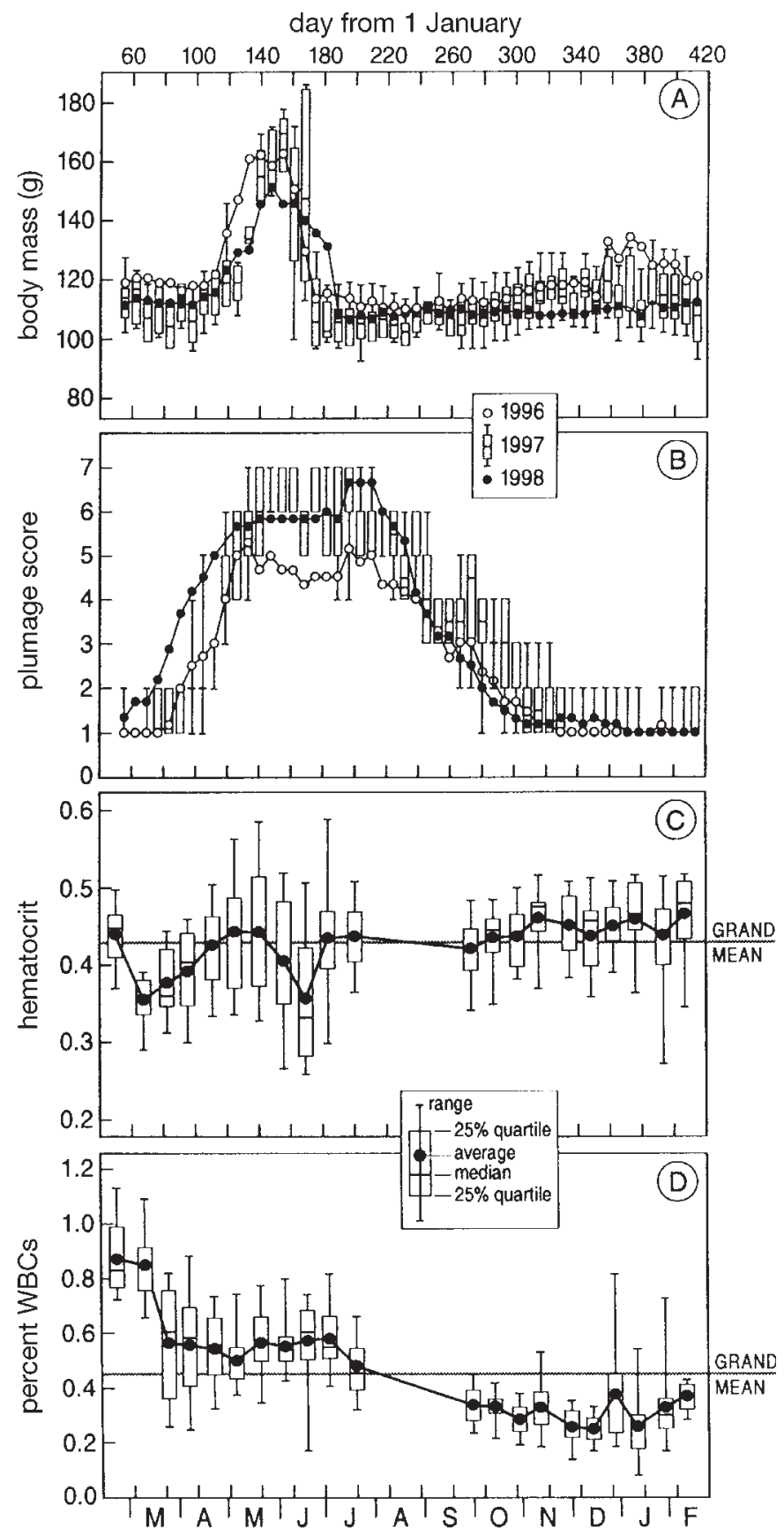

percent WBCs (Fig. 3D). The seasonal changes in percent WBCs (Fig. 4D) were remarkably similar to the pattern in the ruffs (Fig. 1D). Levels started at more than $0.8 \%$ and then declined to about $0.55 \%$; there was a further decrease over the summer to a constant level of about $0.3 \%$.
Fig. 5. Short-term changes in body mass (A), hematocrit (B), and percent WBCs (C) for six red knots during January 1998 as they recovered from a period in which they were allowed to eat only low-quality edible cockles for limited periods of time per day (see the text).
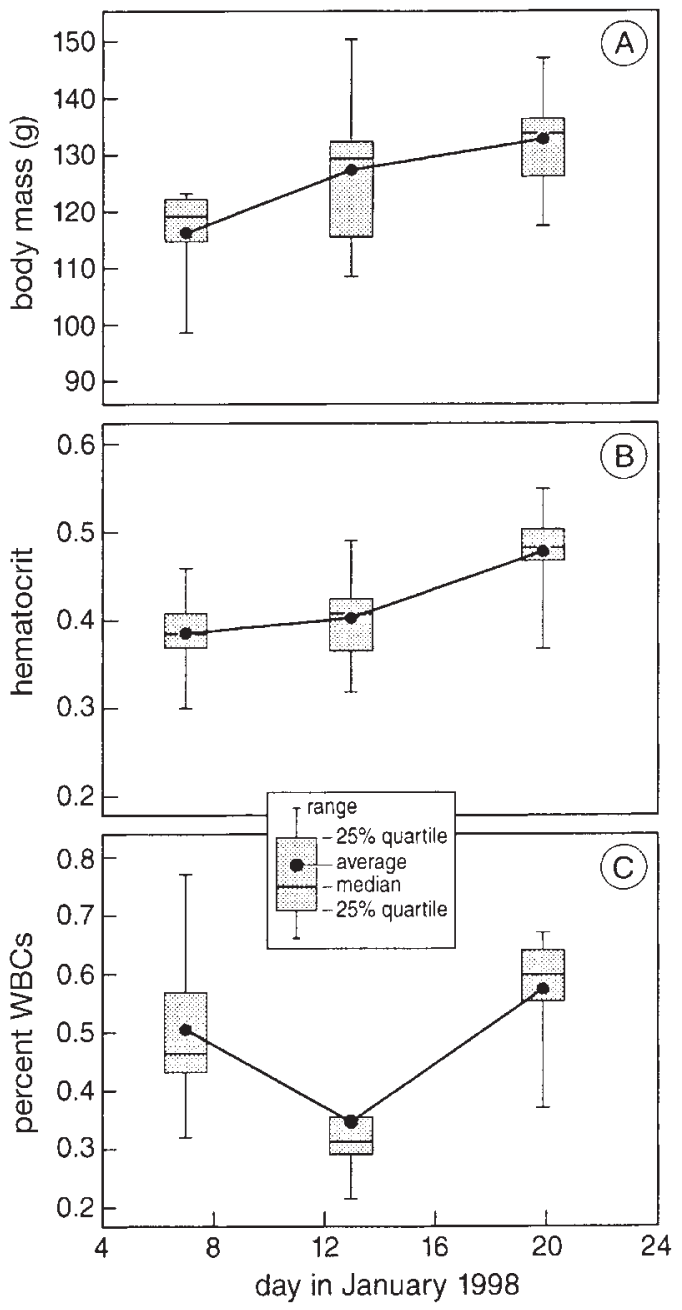

\section{Red knots after a period of restricted feeding}

The day after we discovered that the red knots which had been given a cockle diet had rather thin blood even though body mass values around $115 \mathrm{~g}$ suggested that the birds were healthy (Fig. 5A), hematocrit values were slightly below 0.4 (Fig. 5B). These levels were a little lower than the "normal" midwinter values (Fig. 4C). At the same time percent WBCs (Fig. 5C) were well within the expected range (Fig. 4D). Nevertheless, there were positive correlations between the extent to which the wound healed in the course of the day (on a scale from 1 to 10) and all three variables ( $r$ values were $0.50,0.46$, and 0.70 , respectively; with $n=6$, none of these reached significance at the $5 \%$ level). Interestingly, the extent of healing correlated best with percent WBCs.

By 13 January, after 6 days of supplementary feeding, body mass values had increased by more than $10 \mathrm{~g}$ (Fig. 5A), hematocrit values remained similar (Fig. 5B), and percent WBCs had plummeted (Fig. 5C). A further 7 days of pelletfood supplements led to only a small further increase in body mass, but hematocrit increased to the level (higher than 
0.45) that one might expect for birds in midwinter (Fig. 4C). Percent WBCs had also shown an increase. By 20 January, 2 weeks after we started adding pellets to the shellfish diet of the apparently undernourished knots, their small wounds caused by bleeding healed within about an hour, as in the well-fed trout-pellet-eating birds. Although there was a strong correlation between hematocrit and body mass if data points for the three dates were put together $(r=0.73)$, an analysis of variance showed that it was date (i.e., the time since supplementary feeding started) that explained the variation in hematocrit $(P<0.001)$ and not body mass $(P=0.31)$, with significant variation among the six individuals $(P<0.01)$.

\section{Discussion}

Hüppop (1988) studied three individual captive herring gulls (Larus argentatus) and found strong and consistent seasonal changes in red blood cell counts and hemoglobin levels. Red blood cell counts highest in winter, when ambient temperatures were low and body mass tended to be high. Rather similarly, in four subspecies of Canada geese (Branta canadensis) held in captivity in Ontario, Ronald and George (1988) found hematocrit levels to be lowest in summer. All these findings are not well confirmed by the constant hematocrits of ruffs and the very minor increase in hematocrit of red knots during the second winter period of measurements (note that all these birds faced low temperatures comparable to those experienced by Hüppop's gulls during the same season, December-March). The fact that the captive ruffs were probably tropical winterers may partly explain the discrepancy. Such birds would normally have no need to increase hematocrit levels in winter and thus may have only a limited capacity to respond to environmental stimuli such as low temperature. This suggests that hematocrit level, rather than responses to external factors only, is also affected by an endogenous oscillator.

De Graw et al. (1979) were unable to find differences in hematocrit levels between captive and free-living white-crowned sparrows (Zonotrichia leucophrys gambelii). Yet the average hematocrit value in captive red knots $(0.43)$ was lower than that measured in a sample of free-living red knots mistnetted in the Dutch Wadden Sea on 5-6 August 1998 (mean = $0.48, \mathrm{SD}=0.04$, range $=0.40-0.55, n=26$; T. Piersma, unpublished data). In the case of ruffs we are unable to give comparative data for free-living birds, as Banerjee and Banerjee (1977) measured red blood cell counts and hemoglobin content rather than hematocrit. The increase in hematocrit before long-distance migratory flights reported in free-living bar-tailed godwits (Piersma et al. 1996) may find a weak reflection in the waxing and waning of hematocrit levels in red knots in March-May 1997 (Fig. 4C). That hematocrit levels remained below those attained in midwinter makes us reluctant to fully accept this interpretation: confirmatory observations are required. Nevertheless, that the ruffs showed rather less variation in hematocrit in relation to mass and plumage changes than red knots is consistent with a previous finding that physiological reorganization (in relation to migration) is less drastic in ruffs than in shorebirds like bar-tailed godwits and red knots that routinely make very long flights (Piersma 1998).
For percent WBCs there is as yet little comparative material. Ronald and George (1988) found WBC counts to peak in fall in captive Canada geese. Totzke et al. (1999) experimentally starved herring gulls and found no changes in total WBC count but found a shift in WBC composition from lymphocytes to heterophils, with monocytes and basophils remaining constant and eosinophils being undetectable.

We found no evidence that even this regular and rather intense blood sampling, during which birds lost no less than about $30 \%$ of their blood volume every second week, interfered in any way with their normal physiological and behavioural functions (see also Wingfield and Farner 1976). Colwell et al. (1988) report an anecdote concerning a male Wilson's phalarope (Steganopus tricolor) that inadvertently lost an estimated $40 \%$ of its blood volume in early incubation, but continued incubating and even "allowed" two more bleedings. The seasonal cycles in mass, moult, and plumage of the captive ruffs and red knots appeared to be unaffected; there were no indications that bleeding had negative effects on either hematocrit or percent WBCs. But, as shown by the apparently undernourished red knots and experimentally fasted herring gulls (Totzke et al. 1999), birds may be physiologically less resistant to bleeding if their nutritional status is somehow compromised. This should be taken into account in studies on birds living in conditions that are potentially stressful.

Provided that the animals are nutritionally balanced, we believe that it is not so much the small wound caused by bleeding, or the loss of blood, that is most stressful to birds during blood sampling, but rather the process of catching and handling, especially during sensitive phases of their life cycle like the start of incubation (Colwell et al. 1988). The negative effects reported for birds captured and blood-sampled during the breeding season (Colwell et al. 1988) were due to handling by inexperienced observers rather than to loss of blood. We agree with Colwell et al. (1988) and Lanctot (1994) that the clean and careful taking of blood samples does not put much additional burden on studied shorebirds.

\section{Acknowledgements}

This research was carried out under the auspices of the Animal Experiment Committee of the Dutch Royal Academy of Sciences. We thank Chris W. Pool for guidance. Joop Jukema caught the ruffs and Piet Duiven the red knots. We especially thank Ciska Raaijmakers, Timo Verbeek, and Bernard Spaans for their help. Our work on shorebirds is supported by a PIONIER grant to T.P. from the Netherlands Organization for Scientific Research. This is NIOZ Publication No. 3365.

\section{References}

Baker, A.J., Piersma, T., and Greenslade, A.D. 1999. Molecular versus phenotypic sexing in red knots. Condor, 101: 887-893.

Banerjee, V., and Banerjee, M. 1977. Variations of erythrocyte number and haemoglobin content of a migratory bird: Philomachus pugnax (Linnaeus). Zool. Anz. (Jena), 199: 261-264.

Colwell, M.A., Gratto, C.L., Oring, L.W., and Pizzant, A.J. 1988. Effects of blood sampling on shorebirds: injuries, return rates and clutch desertions. Condor, 90: 942-945. 
Davidson, N.C., and Wilson J.R. 1992. The migration system of European-wintering knots Calidris canutus islandica. Wader Study Group Bull. 64(Suppl.): 39-51.

Dawkins, M.S., and Gosling, L.M. 1992. Ethics in research on animal behaviour. Anim. Behav. 44(Suppl.): 1-64.

de Graw, W.A., Kern, M.D., and King, J.R. 1979. Seasonal changes in the blood composition of captive and free-living white-crowned sparrows. J. Comp. Physiol. 129: 151-162.

Ellegren, H., and Sheldon, B.C. 1997. New tools for sex identification and the study of sex allocation in birds. Trends Ecol. Evol. 12: 255-259.

Ferrer, M., García-Rodríguez, T., Carrillo, J.C., and Castroviejo, J. 1987. Hematocrit and blood chemistry values in captive raptors (Gyps fulvus, Buteo buteo, Milvus migrans, Aquila helicata). Comp. Biochem. Physiol. A, 87: 1123-1127.

Gessaman, J.A., Johnson, J.A., and Hoffman, S.W. 1986. Hematocrits and erythrocyte numbers for Cooper's and sharp-shinned hawks. Condor, 88: 95-96.

Griffiths, R., Daan, S., and Dijkstra, C. 1996. Sex identification in birds using two CHD genes. Proc. R. Soc. Lond. B Biol. Sci. 263: $1251-1256$.

Horãk, P., Ots, I., and Murumägi, A. 1998. Haematological health state indices of reproducing great tits: a response to brood size manipulation. Funct. Ecol. 12: 750-756.

Hüppop, O. 1988. Seasonal changes of erythrocyte numbers and haemoglobin content in the blood of herring gulls Larus argentatus. Seabird, 11: 12-16.

Jukema, J., Piersma, T., Louwsma, L., Monkel, C., Rijpma, U., Visser, K., and van der Zee, D. 1995. Moult and mass changes of northward migrating ruffs in Friesland, March-April 1993 and 1994. Vanellus, 48: 55-61.

Koopman, K. 1986. Primary moult and weight changes of ruffs in the Netherlands in relation to migration. Ardea, 74: 69-77.

Koopman, K., and Hulscher, J.B. 1979. Catching waders with a 'wilsternet'. Wader Study Group Bull. 26: 10-12.

Lanctot, R.B. 1994. Blood sampling in juvenile buff-breasted sandpipers: movement, mass change and survival. J. Field Ornithol. 65: 534-542.

Loye, J.E., and Zuk, M. 1991. Bird-parasite interactions: ecology, evolution and behaviour. Oxford University Press, Oxford.

Lubjuhn, T., Brün, J., Winkel, W., and Muth, S. 1998. Effects of blood sampling in great tits. J. Field Ornithol. 69: 595-602.

Melter, J., and Bergmann, H.-H. 1996. Annual pattern of locomotor activity, moult and body mass in captive ruffs (Philomachus pugnax). Vogelwarte, 38: 169-179.

Ots, I., Murumägi, A., and Horãk, P. 1998. Haematological health state indices of reproducing great tits: methodology and sources of natural variation. Funct. Ecol. 12: 700-707.
Payne, J.M., and Payne, S. 1987. The metabolic profile test. Oxford University Press, Oxford.

Piersma, T. 1998. Phenotypic flexibility during migration: optimization of organ size contingent on the risks and rewards of fueling and flight? J. Avian Biol. 29: 511-520.

Piersma, T., and Davidson, N.C. 1992. The migrations and annual cycles of five subspecies of knots in perspective. Wader Study Group Bull. 64(Suppl.): 187-197.

Piersma, T., and Ramenofsky, M. 1998. Long-term decreases of corticosterone in captive migrant shorebirds that maintain seasonal mass and moult cycles. J. Avian Biol. 29: 97-104.

Piersma, T., Koolhaas, A., and Dekinga, A. 1993. Interactions between stomach structure and diet choice in shorebirds. Auk, 110: $552-564$.

Piersma, T., Cadée, N., and Daan, S. 1995. Seasonality in basal metabolic rate and thermal conductance in a long-distance migrant shorebird, the knot (Calidris canutus). J. Comp. Physiol. B, 165: 37-45.

Piersma, T., Everaarts, J.M., and Jukema, J. 1996. Build-up of red blood cells in refuelling bar-tailed godwits in relation to individual migratory quality. Condor, 98: 363-370.

Prinzinger, R., and Misovic, A. 1994. Vogelblut-eine allometrische Übersicht der Bestandteile. J. Ornithol. 135: 133-165.

Ronald, K., and George, J.C. 1988. Seasonal variation in certain hematological and respiratory properties of the blood of four races of Canada geese, Branta canadensis. Zool. Anz. 220: 7178.

Saino, N., Cuervo, J.J., Ninni, P., de Lope, F., and Møller, A.P. 1997. Haematocrit correlates with tail ornament size in three populations of the barn swallow (Hirundo rustica). Funct. Ecol. 11: 604-610.

Sturkie, P.D. (Ed.) 1986. Avian physiology. 4th ed. Springer-Verlag, New York.

Totzke, U., Fenske, M., Hüppop, O., Raabe, H., and Schach, N. 1999. The influence of fasting on blood and plasma composition in herring gulls (Larus argentatus). Physiol. Biochem. Zool. 72: 426-437.

Wingfield, J.C., and Farner, D.S. 1976. Avian endocrinology-field investigations and methods. Condor, 78: 570-573.

Wingfield, J.C., Schwabl, H., and Mattocks, P.W., Jr. 1990. Endocrine mechanisms of migration. In Bird migration: physiology and ecophysiology. Edited by E. Gwinner. Springer-Verlag, Berlin. pp. 232-256.

Wingfield, J.C., Hunt, K., Breuner, C., Dunlap, K., Fowler, G.S., Freed, L., and Lepson, J. 1997. Environmental stress, field endocrinology, and conservation biology. In Behavioral approaches to conservation in the wild. Edited by J.R. Clemmons and R. Buchholz. Cambridge University Press, Cambridge. pp. 95-131. 